\title{
Spinal epidural gas mimicking lumbar disc herniation
}

Figure $1 \quad$ MRI of the lumbar spine
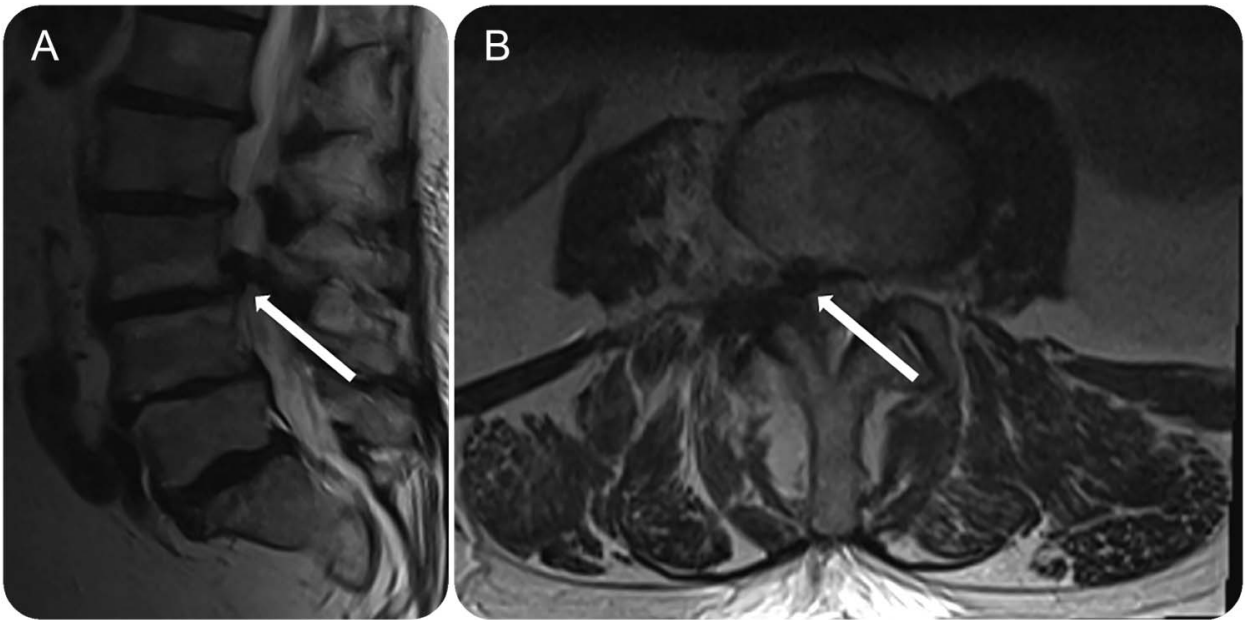

T2 sequences in sagittal (A) and axial orientation (B) illustrate a cranially shifted hypointense mass in the right lateral recessus L3/4 with contact to the nerve root L4 suspicious of a sequestered disc herniation.

A 73-year-old woman presented with acute lower back pain and right sensory radicular L4 syndrome. Spinal MRI showed a cranially shifted T2-hypointense mass suspicious for disc herniation in the L3/4 segment with compression of the right nerve root L4 (figure 1). Due to atypical morphology, CT was performed and disclosed an intraspinal epidural gas bubble mimicking disc herniation on MRI (figure 2). In association with coexisting intravertebral vacuum disc phenomenon (figure 2B), it appears likely that the gas gained access to the epidural space after annulus fibrosus rupture. ${ }^{1}$ Vacuum disc phenomenon results from the accumulation of gas (mostly nitrogen) within the crevices of the disc as it degenerates. ${ }^{1}$

Figure 2 CT of the lumbar spine

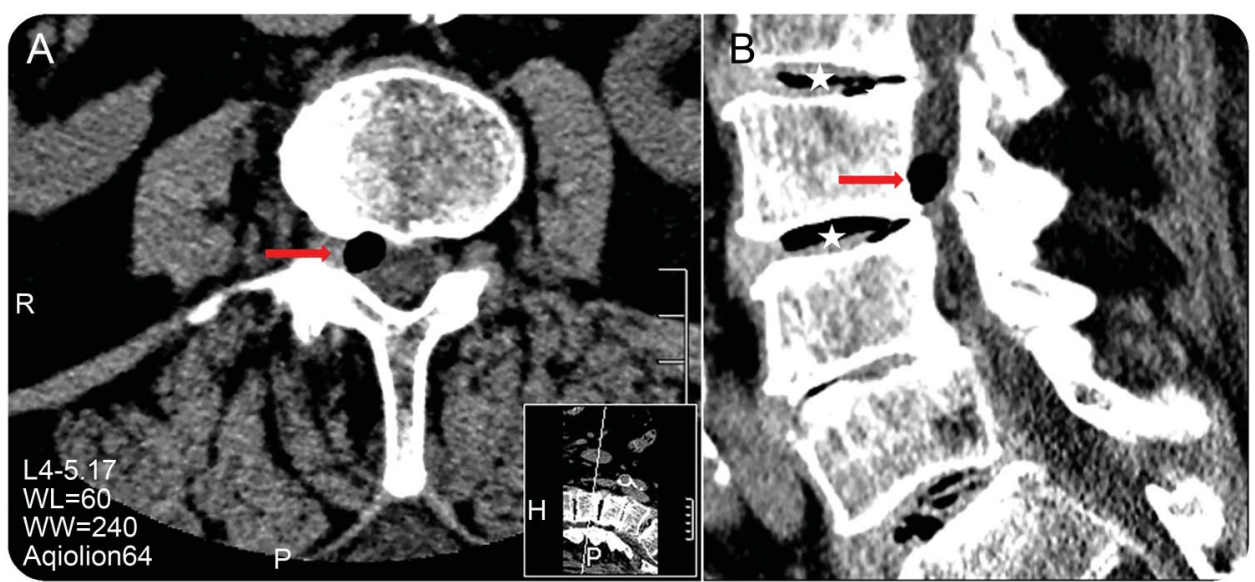

CT reveals an epidural gas bubble mimicking disc herniation on MRI as shown in axial (A) and sagittal (B) cuts (arrows). A coexisting vacuum disc phenomenon (stars in $\mathrm{B}$ ) indicates the presumed origin of the gas bubble. 
Recognizing this condition is crucial for patient management, especially regarding avoidance of neurosurgical procedures.

Eva Hassler, MD, Thomas Gattringer, MD, PhD, Ulrike Wiesspeiner, MD, Hannes Deutschmann, MD, Franz Fazekas, $M D$

From the Division of Neuroradiology, Vascular and Interventional Radiology, Department of Radiology (E.H., U.W., H.D.), and Department of Neurology (T.G., F.F.), Medical University of Graz, Austria.

Author contributions: Eva Hassler: data collection, interpretation of the data, drafting of the manuscript. Thomas Gattringer: data collection, interpretation of the data, revision of the manuscript. Ulrike Wiesspeiner: data collection, interpretation of the data. Hannes Deutschmann: interpretation of the data, revision of the manuscript. Franz Fazekas: study design, interpretation of the data, revision and supervision of the manuscript.

Study funding: No targeted funding reported.

Disclosure: The authors report no disclosures relevant to the manuscript. Go to Neurology.org for full disclosures.

Correspondence to Dr. Hassler: eva.hassler@medunigraz.at

1. Kakitsubata Y, Theodorou SJ, Theodorou DJ, et al. Symptomatic epidural gas cyst associated with discal vacuum phenomenon. Spine 2009;34:E784-E789.

\section{The AAN is Fighting for You!}

In the midst of rapid changes in health care policy, the AAN has your back. From actively lobbying members of Congress to meeting with regulators to underscore the value of neurology and your services to your patients, the Academy is forcefully countering any threats to your profession and patient access to care. Learn more at AAN.com/public-policy, read the bimonthly Capitol Hill Report and monthly AANnews ${ }^{\circledR}$ member magazine, and respond to Advocacy Action Alert emails when we invite you to share your voice with Congress.

\section{Discover Altmetrics}

See real-time downloads and online activity for articles!

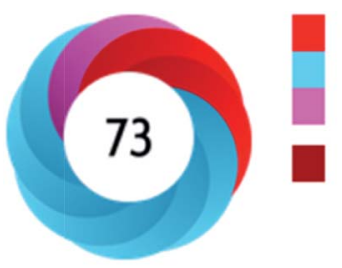

Picked up by 8 news outlets

Tweeted by 18

Mentioned in 1 Google+ posts

12 readers on Mendeley

\section{See more details}

Authors and readers alike can view real-time data on articles including downloads and online activity across multiple sources. Click on the "Article Metrics" link in the right column of an article for details. To learn more about article metrics visit http://www.neurology.org/site/misc/article_usage.xhtml. 


\title{
Neurology
}

\author{
Spinal epidural gas mimicking lumbar disc herniation \\ Eva Hassler, Thomas Gattringer, Ulrike Wiesspeiner, et al. \\ Neurology 2017;89;1528-1529 \\ DOI 10.1212/WNL.0000000000004545
}

This information is current as of October 2, 2017

$\begin{array}{ll}\begin{array}{l}\text { Updated Information \& } \\ \text { Services }\end{array} & \begin{array}{l}\text { including high resolution figures, can be found at: } \\ \text { http://n.neurology.org/content/89/14/1528.full }\end{array} \\ \text { References } & \text { This article cites } 1 \text { articles, } 0 \text { of which you can access for free at: } \\ & \text { http://n.neurology.org/content/89/14/1528.full\#ref-list-1 } \\ \text { Subspecialty Collections } & \text { This article, along with others on similar topics, appears in the } \\ & \text { following collection(s): } \\ & \text { CT } \\ \text { http://n.neurology.org/cgi/collection/ct } \\ \text { Disc disease } \\ \text { http://n.neurology.org/cgi/collection/disc_disease } \\ \text { MRI } \\ \text { http://n.neurology.org/cgi/collection/mri } \\ \\ \text { Information about reproducing this article in parts (figures,tables) or in } \\ \text { its entirety can be found online at: } \\ \text { http://www.neurology.org/about/about_the_journal\#permissions } \\ \text { Information about ordering reprints can be found online: } \\ \text { http://n.neurology.org/subscribers/advertise }\end{array}$

Neurology ${ }^{\circledR}$ is the official journal of the American Academy of Neurology. Published continuously since 1951, it is now a weekly with 48 issues per year. Copyright (O 2017 American Academy of Neurology. All rights reserved. Print ISSN: 0028-3878. Online ISSN: 1526-632X.

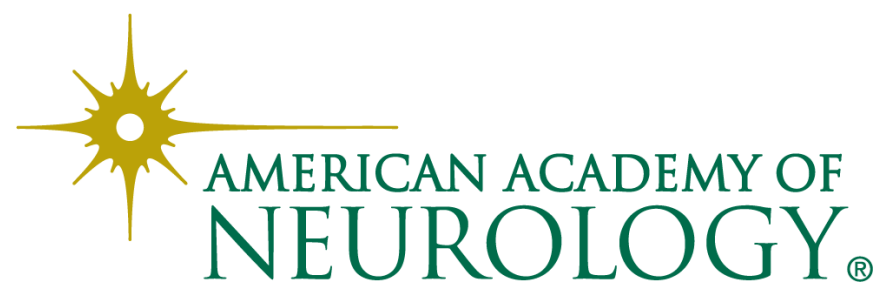

